\title{
O labirinto PoÉtico de Hilda Hilst em JÚbilo, MEMória, NOVICIADO DA PAIXÃO: PERCURSO LÍRICO PELO CORPO, TRADIÇÃO EM ODES DESCONTÍNUAS
}

\author{
Ana Clara Magalhães de MEDEIROS* \\ FRANCISCO JADIR LIMA PEREIRA ${ }^{*}$ \\ MAGNO DA GUARDA ALMEIDA***
}

\section{Resumo}

Nos setenta anos da poesia de Hilda Hilst, destacamos a dialética ausênciadesejo no livro Júbilo, memória, noviciado da paixão (1974). Dois nomes críticos orientam esta pesquisa: Alcir Pécora, no que concerne à crítica literária especializada, e Elisabeth Roudinesco, pela relação com a psicanálise aqui empreendida. Realizamos incursão pelos estudos clássicos para compreensão das odes descontínuas e dionisíacas da obra. Perseguindo a presença/ausência do corpo, chegamos, com o texto, ao corpo político em mal-estar, que requer uma leitura política. Pela relação entre literatura e psicanálise, traçamos estudo analítico dos versos de palavra e corpo desta mulher-poeta.

Palavras-chave: Poesia de Hilda Hilst; Desejo; Corpo; Tradição Clássica.

- Mulher-poeta

E incendiada

Hilda Hilst

* Professora de Estudos Literários na Universidade Federal de Alagoas / UFAL, Alagoas, Maceió, Brasil.

E-mail: ana.medeiros@fale.ufal.br. Orcid iD: https://orcid.org/0000-0002-7218-2187.

** Professor de Estudos Clássicos na Universidade Federal de Alagoas / UFAL, Alagoas, Maceió, Brasil.

E-mail: jadirlpereira@hotmail.com. Orcid iD: https://orcid.org/0000-0002-0497-8554

*** Mestrando no Programa de Pós-Graduação em Linguística e Literatura da Universidade Federal de Alagoas / UFAL, Alagoas, Maceió, Brasil.

E-mail: magnoalmeida.al@gmail.com. Orcid ID: https://orcid.org/0000-0001-8471-8471 
A lírica de Hilda Hilst, septuagenária em 2020, provoca um acontecimento na experiência leitora e corporal do público, uma vez que sua poesia nos impele ao encontro intelectual, mas também corpóreo com o texto. Diante do poema, o corpo pode (e deve) vibrar; brande porque é matéria viva e porque deseja. Herdeiro de Eros e "sinônimo de pulsão de vida” (ROUDINESCO, 2019, p. 109), o poema é um corpo de palavras que deseja o outro - leitor, leitora, leitores, performers.

Desejo é o termo que nos acompanhará ao longo de toda esta proposta, portanto vale começarmos pela epígrafe do vocábulo no Dicionário amoroso da psicanálise, de Elizabeth Roudinesco: "Desejo. O poema é o amor realizado do desejo que permaneceu desejo" (2019, p. 94). Amor e desejo, dois conceitos-experiências inseparáveis, pautam nossa investigação sobre publicação hilstiana em que a falta do outro - do amado - e de outros possíveis produz labirinto repleto de gozo ético e estético pela tradição artística ocidental.

Sob tal influxo, propomos um estudo acerca da relação entre poesia e corporalidade nos poemas de Júbilo, memória, noviciado da paixão (1974) sob o prisma da dialética ausência-desejo. Tomamos a poesia hilstina como lírica do desejo, no sentido de que vozifica e corporifica corpos desejantes - da eu lírica, do amado, do leitor com o objeto-livro. Neste influxo, adentra a tradição ática clássica, com seus mitos e formas que engendraram a tradição do amor e da ausência na lírica ocidental, como se verá. Ainda, observamos ao final deste trabalho, como os versos hilstianos se tornam lírica-política para os homens e as mulheres do nosso tempo - acréscimo nosso ao título da parte derradeira da publicação de 1974, "Poemas aos homens do nosso tempo".

Júbilo, memória, noviciado da paixão merece destaque por trazer de forma singular, entre os títulos poéticos de Hilst, os elementos corpo e desejo. Na percepção de Pécora (2013) - importante nome da crítica especializada sobre a autora - o livro revela uma "poesia eróticometafísica", detentor de uma "dialética erótica, perfeitamente nítida em seu rigor e sistematicidade" (p. 12-13).

Publicada originalmente em 1974, após um longo intervalo sem escrever poesia, foi a obra que fez a crítica testar o valor lírico de Hilda 
Hilst, agora como afirmam Cristiano Diniz e Luisa Destri (2010). Notase, efetivamente, uma mudança significativa provocada pelo impacto da prosa nos seus versos, como, possivelmente, pela nova consciência da autora a respeito de seu ofício como poeta.

A eu poética de Hilst revelada em Júbilo, memória, noviciado da paixão persegue, com a sua poesia, a iminência insuperável do Outro. Para Lacan, outro nome significativo da psicanálise, o desejo é justamente “desejo do desejo do Outro" (ROUDINESCO, 2019, p. 95). O pensador francês recorre aos escritos de Platão para intuir que "uma vez que o amor é desejo, ele também se funda na falta: os objetos do amor são o que não temos, aquilo que nos falta. Lacan, aqui também, inspira-se em Sócrates" (p. 19). Entendemos que, no Brasil dos anos 1970, nossa poeta inspira-se não exatamente em Sócrates o em seu discípulo Platão, mas no conjunto da tradição lírica e dramática da Grécia Antiga para compor seu livro de amor “A M.N.” (HILST, 2013, p. 5). Ao remetermos à tradição ática clássica (em versos e atos), ampla e pilar da literatura ocidental, precisamos indicar que nos restringimos, neste artigo, ao aspecto nuclear do mito em tal legado, bem como às compreensões míticas associadas ao deus Dioniso lidas e redimensionadas na produção poética hilstiana aqui analisada.

Em nosso livro-corpus encontram-se temas explorados amplamente pela poeta, como a paixão, a morte, a ausência do amado, o desejo incessante de consumar um amor impossível - como apontaremos mais adiante em alguns poemas exemplares. Em uma das cartas endereçadas a Júlio Mesquita, Hilda Hilst conta como escolheu o título para seu livro de poemas. Júbilo, memória, noviciado da paixão traz as iniciais desse amigo, Júlio Mesquita Neto. Os poemas, como já dissemos, são dedicados a M. N. - "se eu colocasse J. M. N. todo mundo ia desconfiar, e assim vão pensar que é um Mário Neves qualquer”, argumenta a poeta (HILST apud FOLGUEIRA; DESTRI, 2018, p. 109) ${ }^{1}$. A premissa de que as experiências

As pesquisadoras Folgueira e Destri extraem a fala de Hilda Hilst de carta da escritora endereçada à outra autora, Lygia Fagundes Telles. Trata-se de carta revelada ao público em: TELLES, Lygia Fagundes. Amizades são semelhantes a grandes travessias. O Estado de S. Paulo, 14 fev. 2014. 
pessoais podem estar relacionadas à escrita dialoga com Susana Funck relevante crítica literária feminista - quando esta afirma que "ninguém cria seu mundo ficcional do nada. Escreve-se a partir de uma tradição literária, negociando-se entre significados herdados e posicionamentos alternativos, mas sempre em relação ao que está culturalmente disponível” (FUNCK, 1993, p. 31).

Neste esteio, frisamos que a dedicatória, apenas com iniciais (M.N.), já indica a "dialética erótica" (retomando o Pécora ora citado) que sustém todo o livro: presença desejada/ausência experimentada do outro que serve de mote aos poemas desta publicação. Observe-se que, ao cravar as iniciais na abertura do livro, está marcada essa dinâmica condutora, pois “M. e N." são presenças discursivas do outro que carregam, em si e contraditoriamente, a ausência de um outro definido - que o seria apenas pela redação dos nomes em sua completude. Duas letras que, onde postas, guardam enfim o mecanismo de funcionamento do desejo, conforme interpretações de Lacan e Roudinesco: desejo alicerçado na falta, poema como corpo permanente do desejar.

Dentre os sete pequenos livros que compõem a publicação de 1974, o que mais diretamente remete à tradição mítica grega é, como se pode supor, "Ode descontínua e remota para flauta e oboé. De Ariana para Dionísio”. Deste, extraímos o segundo canto que muito evidentemente revela a relação imbricada entre ser poeta e existir corpo:

II

Porque tu sabes que é de poesia

Minha vida secreta. Tu sabes, Dionísio,

Que a teu lado te amando,

Antes de ser mulher sou inteira poeta.

E que o teu corpo existe porque o meu

Sempre existiu cantando. Meu corpo, Dionísio,

É que move o grande corpo teu.

Ainda que tu me vejas extrema e suplicante

Quando amanhece e me dizes adeus

(HILST, 2013, p. 60). 
Desde uma primeira leitura do poema, observa-se núcleo lexical que aponta, por si mesmo, para aquela dialética erótica que frisamos com Alcir Pécora: poesia, mulher, corpo. O início do canto com a conjunção "porque" espanta o leitor habituado a textos mais convencionais pela ausência de elementos anteriores que pressuponham a necessidade de uma pergunta, a ser então explicada na estrofe. Essa ausência, contudo, de perguntas motivadoras do "porque" desmascaram, novamente, a solidão da eu lírica, que dialoga com o outro - sem a participação desse outro. Ainda, o início do verso com o termo explicativo acentua que então se verá uma explanação. Assim, a poeta constitui, em todo o canto, uma argumentação que visa convencer o interlocutor, agora nominado como incorporação do deus grego Dionísio.

A voz poética ressalta, como quem resume, a dinâmica de sua existência: mulher que antes disso é poeta (verso 4) e que, portanto, tem na poesia seu existir. Se a vida requer corpo, existem dois: o do amado, mas, antes, o daquela que "sempre existiu cantando" (6). Ora, viver para cantar pode ser definição máxima da condição de poeta em tempos diversos da jornada lírica em qualquer tempo e língua.

Antes de avançarmos, cumpre dizer que o título deste quarto "livro", onde se apresenta o canto da poeta "extrema e suplicante" (8), remete a duas linhagens artísticas produtivas (e que se entrecruzam) em Júbilo, memória, noviciado da paixão: a da tradição musical ("flauta e oboé”) e a da tradição lírica ocidental ("ode”; "de Ariana para Dionísio"). Descortinamos com mais minúcia cada uma delas a seguir.

A primeira, tradição musical associada à poesia é notadamente herança da imbricada relação entre versos, canto e lira - instrumento grego que permitiu a fixação do termo lírica para designar o gênero literário enformado em poemas. Tal tradição é acionada deliberadamente, em Júbilo, memória, noviciado da paixão, nas seguintes partes: "Moderato cantábile", "Prelúdios intensos para os desmemoriados do amor", "Árias pequenas. Para bandolim".

Já a segunda tradição apontada remete ao desenvolvimento do gênero poético no ocidente e em língua portuguesa, isto é, as faces e corpos 
da poesia em momentos distintos na história mundial: nas odes de Alceu, Safo e Píndaro, na poesia jâmbica de Arquíloco, nas odes de Horácio, nas cantigas trovadorescas medievais, nos sonetos de Petrarca, na lírica amorosa de Camões, Tomás Antônio Gonzaga, até chegar em composições multiformes que marcam a primeira metade do século $\mathrm{XX}$, a partir de nomes como Florbela Espanca, Manuel Bandeira e Vinicius de Moraes. Na segunda porção dos anos 1900, chegam-nos os poemas de Hilda Hilst, que são, por um lado, inovadores na consecução de uma poética líricocorporal feminina em nossa língua; por outro, são tributários e resultantes desse arcabouço poético vasto que muito brevemente elencamos. O diálogo hilstiano com tal tradição lírica verifica-se nitidamente nas seções ou pequenos livros seguintes: "Dez chamamentos ao amigo", "O poeta inventa viagem, retorno, e sofre de saudade", "Poemas aos homens do nosso tempo".

Observamos que "Ode descontínua e remota para flauta e oboé. De Ariana para Dionísio” congrega exatamente a fusão entre uma linhagem eminentemente musical e outra pautada nos desdobramentos líricos da mítica grega. Se a forma "ode" não é, ela mesma, a junção entre palavra e música, sendo ōidē do grego "um canto com música” (PEREIRA, 1998, p.639), isto é, palavra acompanhada de instrumento.

Esse quarto livro de Júbilo, memória, noviciado da paixão é composto por dez cantos, residindo, nesta saga amorosa, memória distante da saga política, econômica, mas também corpórea (e deveras violenta) empreendida pelos portugueses no processo colonial e entoada n'Os Lusíadas (1572), de Camões, tradicional épico seiscentista de Língua Portuguesa também disposto em dez cantos. Registramos, com Pécora, a "matriz arcaizante" que segue "à maneira [...] camoniana" (PÉCORA, 2013, p. 12) de Hilda Hilst. Toda a publicação de 1974 conserva uma memória camoniana, cumpre dizer. Mais o Camões sonetista, como quer Alcir Pécora, concordamos. Entretanto, vale voltar atenção para a incidência também do vulto camoniano épico na obra em que o poeta "inventa viagem, retorno, e sofre de saudade" (HILST, 2013, p. 29). Trata- 
se, esta última citação, de título da segunda seção da obra aqui analisada, mas pode também ser entendida como síntese da literatura lusitana fundada sobre o viajar, o nóstos (do grego, "retorno", "viagem de volta") e a marca da saudade, inerente aos viajantes e aos que ficam, todos padecentes da ausência. Ausência que engendra desejo, outra vez o revemos como marca da lírica hilstiana.

A compositora das odes para Dionísio é ninguém menos que Ariana, variante de Ariadna ou Ariadne: "o nome é um composto da partícula aumentativa ả pl- e de ả $\delta$ ós, que, segundo uma glosa de Hesíquio, seria uma versão cretense para óyvós, 'sacro, puro'; significaria, portanto, 'a santíssima” (DEMGOL, 2013, p. 30). Ariadne, a mulher abandonada por Teseu, na ilha de Naxos, e resgatada pelo amor do deus Dionísio. $\mathrm{Na}$ versão lírica brasileira para o mito cretense, Dionísio, tal como Teseu, dá adeus à mulher: "quando amanhece e me dizes adeus" (9). Apesar da ausência masculina, adverte a eu lírica: “Tu sabes, Dionísio,/Que a teu lado te amando,/Antes de ser mulher, sou inteira poeta” (2-3-4-). A inteireza da mulher, como dissemos, advém da experiência da ausência feita fazer poético: "Porque tu sabes que é de poesia/Minha vida secreta" (1-2).

Assinala a poeta que "o fio de Ariadne" tece uma ode privada cujo erotismo ou sedução se instaura através da palavra profanada, revelada ao amante, da mesma forma que, outrora, a princesa de Creta apontara os segredos do labirinto ao herói ateniense. Dionísio é o novo amante, o ideal sublime, o objeto de desejo ardente de Ariadne/Ariana. Ao deus da loucura, das paixões delirantes, é permitido conhecer os mistérios desta Ariadne não somente em sua dimensão de "mulher", mas ainda, naquela menos evidente, inacabada e labiríntica, a de ser "poeta":

\footnotetext{
$\mathrm{X}$

Se todas as tuas noites fossem minhas

Eu te daria, Dionísio, a cada dia

Uma pequena caixa de palavras

Coisa que me foi dada, sigilosa
} 
E com a dádiva nas mãos tu poderias

Compor incendiado a tua canção

E fazer de mim mesma, melodia.

[...]

(HILST, 2013, p. 68).

Ariana traz nesses versos sua essência feminina herdada da primeira mulher, na concepção ática: Pandora ${ }^{2}$. Aquela oculta um mistério, mas está disposta a abrir sua "pequena caixa de palavras" para que Dionísio possa compor canções e melodias. Eis, assim, a "dádiva”, o dote da princesa para consolidar o himeneu com o deus. No verso "Se todas as tuas noites fossem minhas" (1) resiste o pedido da amante desejosa por tomar posse do corpo do amado - sempre sagrado e metafísico, divino, por ausente.

Os corpos fundem-se, neste canto, neste "pequeno livro", como em todo este livro da autora, em poesia. Deste casamento entre o profano e o sagrado, entre a palavra e a canção, nasce a ode, lato sensu, a poesia. Júbilo, memória, noviciado da paixão, portanto, é amálgama de corpo e poesia: "[...] o teu corpo existe porque o meu/Sempre existiu cantando. Meu corpo, Dionísio,/É que move o grande corpo teu” (7). O corpo, como a existência de Dionísio, nesta obra lírica, existe porque "o amor engendra o discurso amoroso" (ROUDINESCO, 2019, p. 19-20) e tal discurso se faz forma lírica.

Na poética hilstiana, corpo e desejo se ramificam pelos poemas compondo vasta teia de significados e interpretações. Uma dessas ramificações, é certo, está na vivência/ausência do amor associado à procura incessante por um ser que nunca está presente. Logo, entende-se que a ausência engendra desejo - que palavrado é verso, poema, o livro Júbilo, memória, noviciado da paixão. Evocando Roland Barthes, temos que "o desejo do ser ausente e o desejo do ser presente" sedimentam o amor: "o langor sobrepõe os dois desejos, põe a ausência na presença” (BARTHES, 2003, p. 235).

2 Pandora: “o nome é um composto de $\pi \tilde{\alpha} \varsigma$, 'todo', e $\delta \tilde{\omega} \rho o v$, 'presente, dom', e tem um valor possessivo; [...] significa 'a que possui todos os dons da parte dos deuses”” (DEMGOL, 2013, p. b221). 
A obra Fragmento de um discurso amoroso (2003), do pensador francês estudioso da "escritura" não tem como objetivo a tarefa de analisar o amor, mas investigar a forma como ele se expressa no discurso amoroso. Tal dizer amoroso parece ainda mais evidente na primeira parte de Júbilo, memória, noviciado da paixão, intitulado Dez chamamentos ao amigo que, aliás, tem por epígrafe "love, love, my season", de Sylvia Plath. Se tomamos "season", do inglês, por "estação", acepção mais comum do termo, entendemos que o amor é a estação da poeta, mas também o é dos dez cantos, dez passagens, dez estações da Ariana que fazer existir o livro para Dionísio, ou para M.N.

Do primeiro dos sete livros de nosso livro, retomamos poema angular, o quarto:

\section{IV}

Minha medida? Amor.

E tua boca na minha

Imerecida.

Minha vergonha? O verso

Ardente. E o meu rosto

Reverso de quem sonha.

[...]

(HILST, 2013, p. 20).

Neste solilóquio, a eu poética impõe a "estação" (season), que se faz medida de seus versos, de seu discurso: "Amor". A proposição é cantar "as coisas do amor" (tà erotiká). Para tratar de um assunto tão sublime, persiste memória de gênero da poesia épica, sendo necessário a evocação do amado. Todos os poemas de Dez chamamentos ao amigo clamam pelo amigo ausente-desejado. Ela evoca do amado, a "memória", Mnemosyne, mãe das musas, para que se instaure o "júbilo", o êxtase dionisíaco, a orgia, “o verso ardente" (4-5).

Disso apreendemos que poesia, corpo lírico e corpo autoral imiscuem-se na composição hilstiana. Retomando o livro de "Ariana para 
Dionísio", a que oferecemos maior destaque nesta proposta analítica, continua a poeta, no canto terceiro:

\section{III}

A minha Casa é guardiã do meu corpo

E protetora de todas as minhas ardências.

E transmuta em palavra

Paixão e veemência

E minha boca se faz fonte de prata

Ainda que eu grite à Casa que só existo

Para sorver a água da tua boca.

A minha Casa, Dionísio, te lamenta

E manda que eu te pergunte assim de frente:

À uma mulher que canta ensolarada

E que é sonora, múltipla, argonauta

Por que recusas amor e permanência?

(HILST, 2013, p. 61).

Destacamos alguns elementos que apontam, no poema (canto), para a existência de um corpo vivo e desejante: "meu corpo", "minhas ardências", "minha boca”, "eu grite”, "sorver a água da tua boca”, "mulher que canta" e "ensolarada", "sonora" e "argonauta”. Note-se que os termos "corpo", "boca", "gozo" são reincidentes e insistentes também neste livro que trata de uma grande ausência - de Túlio, de Dionísio, do amado. A pergunta do verso derradeiro - solitário como a poeta e sua angústia condensa sofrimento porque não recebe resposta ao longo de todo o livro: “Por que recusas amor e permanência? ”. Não acessamos discurso algum do interlocutor, mas sabemos, pela linhagem interpretativa da psicanálise que temos evocado, ser justamente este silêncio sintoma imaterial da falta: condição para permanência do desejo.

A primeira estrofe do poema citado permite perceber claramente que "Casa”, com maiúscula, para a voz lírica, é o que, a um só tempo, 
protege seu "corpo", "suas ardências" e transforma "paixão e veemência" (4) em "palavra”. Casa, portanto, é o poema, a poesia sua - fiel ao corpo, guardiã de palavras.

Da primeira estância, pulamos para a terceira, por sua memória trágica: o verbo "lamentar", ao lado do nome de Dionísio, merece maior atenção. Precisamos, neste ponto, fazer incursão mais demorada pelos estudos clássicos. Eudoro de Sousa, pensador lusitano da arte grega, sugere ser de Teofrasto (filósofo de Lesbos discípulo de Aristóteles) a definição de que "a tragédia é um poema (representado) sobre um túmulo" (SOUSA, 1986, p. 51). Nesta linha, o "kommós” - lamento fúnebre torna-se essencial ao canto trágico, à revelia do que preconiza o próprio Aristóteles, em sua Poética (SOUSA, 1986).

Essa retomada clássica desponta como necessária posto ser Dionísio - interlocutor-ausente evocado pela Ariana de Hilst - precisamente o deus motriz do gênero trágico, na medida em que a grande arte de Sófocles e Ésquilo constitui culto ao deus-bode (conforme entendimento mais ou menos consensual dos helenistas a partir de Nietzsche).

Assim, se a "Casa" da poeta lamenta Dionísio, o poema ganha contornos trágicos, feito lamúria em homenagem dionisíaca: "Por que recusas amor e permanência" (12). Se persistimos em nossa investigação pelos estudos helênicos, concordamos com Nietzsche quanto ao caráter labiríntico dessa travessia: "[...] a fim de nos orientarmos no labirinto, pois é assim que devemos designar a origem da tragédia grega" (NIETZSCHE, 2000, p. 51). Longe de querermos empreender percurso similar ao do filósofo alemão, registramos apenas que Ariana - a conhecida Ariadne do labirinto de Minotauro - é personificação feminina das odes-avessas de Hilda Hilst. Nelas, empreende-se caminhada lírica por um labirinto da ausência: onde não se encontram Teseu, Dionísio, Túlio, M. N. ou qualquer amado.

Reside na Casa - que é corpo e labirinto - "uma mulher que canta ensolarada”. Neste verso, Hilst recupera toda uma tradição mítica de mulheres solares. Ariana (Ariadne) é filha da rainha e feiticeira Pasífae que, por sua vez, é filha de Hélio, deus do Sol, e da oceânida Perseida. Do divino Hélio, Ariana herda o caráter ensolarado, luminoso, ardente, 
enquanto, da sacra Perseida, recebe a dádiva oceânica, fluida, "sonora, múltipla, argonauta”, o encantamento através das palavras. Vale esclarecer

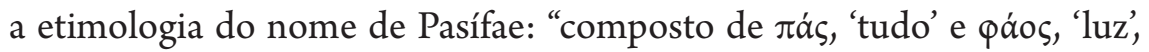
[...] significa 'inteira esplendorosa', sem dúvida em conexão com suas 'origens solares”' (DEMGOL, 2013, p.227). A este catálogo de mulheres solares, somam-se: Circe, a feiticeira filha de Hélio, e Perseida, portanto, tia de Ariana; Medeia, a feiticeira cujos encantamentos auxiliaram Jasão e os demais argonautas a conquistar o velocino de ouro. A princesa da Cólquida é sobrinha de Circe e neta do deus luminoso. Na tragédia euripidiana que leva seu nome, Medeia foge no carro de Hélio: "O Sol, pai de meu pai, me deu este carro como meio de defesa contra mãos inimigas. " (EURÍPIDES, 2008, p. 101).

Transpondo as barreiras do mito, do tempo e do espaço, urge dizer que "casa, corpo e sol" remetem-nos a poema que abre o "pequeno livro" Árias pequenas. Para bandolim - penúltima seção da obra de Hilst:

I

Os dentes ao sol

A memória engolindo

O resplendor angélico

De um lívido jacinto.

Os dentes ao sol

E o escuro momento

Do girassol no muro

Enlouquecendo.

Os dentes ao sol

Dentro de mim

A sombra dos teus dedos

Tua brusca despedida.

Do tempo

As enormes mandíbulas

Roendo nossas vidas

(HILST, 2013, p. 79). 
Como explicitado anteriormente, em muitos dos poemas de Hilst, encontramos o corpo da eu lírica ligando-se ao corpo da palavra, através do desejo. De certo modo, é possível supor que o corpo sente e diz via poema. Segundo Barthes (1977, p. 49), "o livro faz o sentido, o sentido faz a vida”. A vida soma amor e morte, como entende a psicanálise de Freud, Lacan e Roudinesco: "O amor é o companheiro da morte, dizia Freud, juntos, eles governam o mundo" (ROUDINESCO, 2019, p. 110).

O verso "os dentes ao sol" (9) constitui um antecanto (repetição de um verso no início da estrofe) macabro e solar ao mesmo tempo. A última estrofe destaca-se das três anteriores por não conter tal antecanto. Por isso mesmo, por essa ausência, oferece mote para significação das estrofes antecedentes: os dentes formam "enormes mandíbulas" (14) que vão "roendo nossas vidas" (15). O tempo come, rói, os corpos e suas vidas ao sol. Nos três (curtos, "pequenos") quartetos iniciais, o segundo verso sempre oblitera a proposta solar (possível sorriso) do antecanto. Primeiramente, "a memória engolindo" (2) o "resplendor angélico", o aroma "lívido" de um "jacinto". Em seguida, "o escuro momento" (6) de um "girassol" - planta e palavra tecida de sol - "enlouquecendo" (8). Para finalmente chegar-se à "brusca despedida" (12), se o sol sumiu "dentro de mim" (10), dentro da eu lírica não tocada pelos dedos do amante abandonada, como Ariadne/Ariana, contempla apenas "a sombra dos teus dedos" (11), dedos ausentes na existência roída pela falta do outro, pela presença do tempo.

A melancolia toma essa aparentemente despretensiosa cantiga de amor - e morte (lembre-se do komós lutuoso da tragédia grega). As rimas externas das duas primeiras estrofes - nasais, consonantais, rematadas pela sisuda vogal "o" entoam o clima de morbidez: "engolindo" e "jacinto" (2 e 4) na primeira quadra. Em seguida, a inversão da consoante oclusiva ("d" por "t") embala a rima que começa a abrir-se em vogal "e": "momento" e "enlouquecendo" (6 e 8). Na terceira quadra, a impressão penosa fica a cargo dos encontros consonantais " $\mathrm{b}$ " / " $\mathrm{t}$ " + "r", de "dentro", "sombra" e "brusca" (10-11-12) que interrompem bruscamente a proposta vocálica solar do antecanto: "os dentes ao sol". Ocorre que a vocálica "despedida" 
(12) rima com a derradeira palavra "vida" (15). Qualquer potência solar, aberta, emanada pelas vogais "e" e" "a" é sepultada pela languidez das nasais que antecedem "vida", a saber: "tempo", "mandíbulas", "roendo" (13-1415).

Não é em vão que poema de tão criteriosa construção lírica, com atenção pormenorizada aos processos rímicos e rítmicos, apareça na seção que leva no título a expressão "Para bandolim". Trata-se de instrumento despontado na Europa, nos séculos XVI e XVII, justamente quando ainda circulavam as cantigas e baladas populares, como os tradicionais sonetos líricos de Camões em Portugal. Observe-se que o canto I de Hilst, ora citado, não se adequa à forma soneto pelo excesso de apenas um verso. Ainda, vale ressaltar que o bandolim - incidente no título do "pequeno livro" - popularizou-se no Brasil com os choros ou chorinhos, gênero musical brasileiro instrumental e cantado que usualmente envolve relatos amorosos e alguma melancolia provocada pelas "baixarias do violão" (TINHORÃO, 2010, p. 316).

Feito esse importante percurso pelos labirintos líricos e musicais tradicionais presentes na poesia de Hilda Hilst, podemos avançar em direção ao nosso tema final: a incidência de um "dialética-erótica" e política (PÉCORA, 2013, p. 12) no "pequeno livro" final de Júbilo, memória, noviciado da paixão. Os dentes, mote para o poema recémanalisado, aparecem agora, em Poemas aos homens do nosso tempo como chave de ouro de uma gente roída pelas artimanhas de políticos:

II

Amada vida, minha morte demora.

Dizer que coisa ao homem,

Propor que viagem? Reis, ministros

E todos vós, políticos,

Que palavra

Além de ouro e treva

Fica em vossos ouvidos?

Além da vossa RAPACIDADE

$\mathrm{O}$ que sabeis 
Da alma dos homens?

Ouro, conquista, lucro, logro

$\mathrm{E}$ os nossos ossos

E o sangue das gentes

E a vida dos homens

Entre os vossos dentes

(HILST, 2013, p. 107).

Notamos que, a partir desse ponto, a ausência (de um amado, cantada em todas as anteriores seis partes) transmuta-se em uma espécie de falta da "alma dos homens". Assim, o homem - amado, desejado, interlocutor lírico - passa a ser agora sujeito genérico, todos eles: "Reis, ministros", "políticos". Homens feitos de "ouro e treva" que não sabem nada da "vida dos homens" e tomam-lhes o sangue "entre os dentes”. Não há mais viagem que o poeta possa inventar, retornar e sofrer de saudade. Nenhuma palavra subsiste além da capitular RAPACIDADE - avidez pelo lucro, ouro, voracidade sobre a presa ("nossos ossos", em um mundo aviltado por sofrimentos e decepções alastradas, como veremos em seguida).

Abundam, nesta parte final da obra, termos como "morte", "mortos", "carne”, "sangue”, "política”, "poeta”. Os "Poemas aos homens do nosso tempo", desse modo, fogem à lógica formal e temática tributária do discurso amoroso entre uma Ariana e um Dionísio/Túlio para adotarem forma e tom prosaicos, versos livres, longos, poemas dedicados a figuras históricas - como ao poeta Federico García Lorca, fuzilado pelo regime franquista durante a Guerra Civil Espanhola. Sobre o poema em sua homenagem, aliás, urge destacar alguns versos: "Ah, se soubesses como ficou difícil a Poesia./Triste garganta o nosso tempo, TRISTE TRISTE” (7-8) (HILST, 2013, p. 109). Aqui, leitoras e leitores deparam-se, enfim, com um conjunto artístico que revela o padecer do corpo coletivo diante da morte, da guerra, do ódio, dos palanques, dos "homens políticos”. A insurgência da eu lírica - outrora pastora amorosa ou argonauta apaixonada - agora se prorrompe para denunciar que "os nossos ossos" / "o sangue das gentes" / 
"a vida dos homens" e o destino da "Poesia" foram tragados pela "Triste garganta" que é "o nosso tempo".

Transitando pela dialética desejo-ausência de um único amado e o princípio do prazer coletivo de encontrar felicidade enquanto se vive, a poeta Hilda Hilst finca sua poética no domínio de Eros: pulsão de vida, caminho para a morte. Parece-nos inevitável recorrer ao próprio Freud precisamente o de "Mal-estar na civilização":

A vida, tal como a encontramos, é árdua demais para nós; proporciona-nos muitos sofrimentos, decepções e tarefas impossíveis. [...] O que pedem eles [os próprios homens] da vida e o que desejam nela realizar? A resposta mal pode provocar dúvidas. Esforçam-se para obter felicidade; querem ser felizes e assim permanecer. [...] Nossas possibilidades de felicidade sempre são restringidas por nossa própria constituição. Já a infelicidade é muito menos difícil de experimentar. O sofrimento nos ameaça a partir de três direções: de nosso próprio corpo [....]; do mundo externo, que pode voltar-se contra nós com forças de destruição esmagadoras e impiedosas; e, finalmente, de nossos relacionamentos com os outros homens (FREUD, 2006, p. 83-85).

Ora, Júbilo, memória, noviciado da paixão, de Hilda Hilst, desponta como obra poética em que o desejo e a falta coabitam com a impossibilidade da felicidade e a experiência do sofrimento. Observamos que os sete pequenos livros que formam o livro analisado comportam os três tipos principais de ameaças do sofrimento indicados pelo mestre da psicanálise. Afinal, analisamos uma figura lírica que tanto goza quanto padece pelo corpo. O relacionamento com "o amigo", Túlio, Dionísio ou o interlocutor inominado confere à poeta existência, pulsão de vida, mas também frustração, dor pela falência do amar.

Finalmente, a seção derradeira da publicação de 1974 revela-nos um "mundo externo" que se volta "contra nós com forças de destruição esmagadoras e impiedosas" a destruir a "amada vida”, a "palavra-livre”, o “Homem-Amor” (HILST, 2013, p. 117; 118; 121). Não, no mundo "não 
há bombas limpas", dizem Mário Faustino e a eu poética-política de Hilda Hilst. Existe, isso sim, a suma infelicidade causada pelo "homem-político", pelos "homens-hienas", pelos "dirigentes do mundo" (12) (HILST, 2013, p. 123).

Ao final de nosso percurso lírico, certamente ecoa a convicção de que "Cantando amor, os poetas na noite/ Repensam a tarefa de pensar o mundo" (15-16) (HILST, 2013, p. 105). Quanto pensou o mundo, a poeta solar Ariadne/Ariana/Hilda, que neste ano se faria nonagenária. Repensando continuamente a tarefa de "fazer pensando" este mundo, lega-nos Júbilo, memória, noviciado da paixão, obra labiríntica, no sentido mítico clássico, pela qual empreendemos algumas travessias - se o "amor é sempre travessia" (HILST, 2013, p. 32).

Sendo o desejo marca experimentável da falta perene, entendemos que o livro poético aqui estudado provoca reflexões acerca da própria condição humana, conclamando os homens e as mulheres de nosso tempo a se demorarem sobre eros e sobre sua relação com o mal-estar e o morrer na história do mundo. O metro de Hilda Hilst é duplo: "Porque o instante consente essas duplas medidas" (7) (HILST, 2013, p. 126). Desejo e falta, vida e morte, outro-meu e outro-nosso - duplas medidas da poética contemporânea e clássica dessa que foi "mulher-poeta/ E incendiada” (22-23) (HILST, 2013, p. 88). Por isso mesmo, sua lírica do desejo permanece como ōidè aos viventes de nosso tempo.

HILDA HILST'S POETIC LABYRINTH IN JÚBILO, MEMÓRIA, NOVICIADO DA PAIXÃO: A LYRICAL JOURNEY THROUGH THE BODY, TRADITION IN DISCONTINUOUS ODES

\section{AbStract}

In the seventy years of Hilda Hilst's poetry, we highlight the dialectic absencedesire in her book Júbilo, memória, noviciado da paixão (1974). Two critical names guide this research: Alcir Pécora, regarding the specialised literary criticism, and Elizabeth Roudinesco, for the link with the psychoanalysis undertaken 
in this article. We make an incursion into classical studies to understand the discontinuous and Dionysian odes of her work. Pursuing the presence/absence of the body, we got to the political discomfortable body which requires a political reading. Through the relationship between literature and psychoanalysis, we propose an analytical study of the word and the body verses of this woman-poet. KeYwords: Hilda Hilst's poetry; Desire; Body; Classical Tradition.

El laberinto poético de Hilda Hilst en JÚbILO, MEMóRIa, NOViciado DA PAIXÃO: CAMINOS LÍRICOS A TRAVÉS DEL CUERPO, TRADICIÓN EN ODAS DISCONTINUAS

\section{RESUMEN}

En los 70 años de la poesía de Hilda Hilst, destacamos la dialéctica ausencia-deseo en el libro Júbilo, memória, noviciado da paixão (1974). Dos nombres críticos orientan esta investigación: Alcir Pécora con respecto a la crítica especializada, y Elisabeth Roudinesco por la relación con psicoanálisis emprendida. Hicimos incursión por los estudios clásicos para comprender las odas discontinuas y dionisiacas de la obra. Persiguiendo la presencia/ausencia del cuerpo, llegamos, con el texto, al cuerpo político en malestar, lo que requiere una lectura política. Desde la relación entre literatura y psicoanálisis trazamos estudio de los versos de palabra y cuerpo de esta mujer-poeta.

Palabras clave: Poesía de Hilda Hilst; Deseo; Cuerpo; Tradición clásica.

\section{REFERÊNCIAS}

BARTHES, Roland. Fragmentos de um discurso amoroso. Tradução de Márcia Valéria Martinez de Aguiar. São Paulo: Martins Fontes, 2003. . O prazer do texto. Tradução de J. Guinsburg. São Paulo: Perspectiva, 1977. 
CAMÕES, Luís de. Os Lusíadas. Edição organizada por Emanuel Paulo Ramos. 3. ed. Porto: Porto Editora, 2000.

CAMÕES, Luís de. Sonetos de Camões. Edição organizada por Izeti Fragata Torralvo e Carlos Cortez Minchillo. Cotia, SP: Ateliê Editorial, 2001.

DEMGOL. Dicionário Etimológico da Mitologia Grega. Pandora. 2013. Disponível em: <https://demgol.units.it/pdf/demgol_pt.pdf >. Acesso em: 21 fev. 2020.

DINIZ, Cristiano; DESTRI, Luisa. Um retrato do artista. In: PÉCORA, Alcir (Org.). Por que ler Hilda Hilst. São Paulo: Globo, 2010. p. 31-55.

DINIZ, Cristiano. Fortuna Crítica de Hilda Hilst: levantamento bibliográfico 1949 -2018. São Paulo: Unicamp, 2018.

EURÍPIDES. Medeia. Introdução, versão do grego e notas Maria Helena da Rocha Pereira. 4. ed. Lisboa: Fundação Calouste Gulbenkian, 2008. FOLGUEIRA, Laura; DESTRI, Luisa. Eu e não outra: a vida intensa de Hilda Hilst. São Paulo: Tordesilhas, 2018.

FREUD, Sigmund. O mal-estar na civilização. O futuro de uma ilusão, o malestar na civilização e outros trabalhos. Obras psicológicas completas de Sigmund Freud: edição standard brasileira. Tradução de Jayme Salomão. Rio de Janeiro: Imago, 2006. p. 73-148. (v. 21).

FUNCK, Susana Bornéo. Feminismo e utopia. Revista Estudos Feministas, Rio de Janeiro, v. 1, n. 1, p. 33-48. 1993.

HILST, Hilda. Júbilo, memória, noviciado da paixão. São Paulo: Globo, 2013.

NIETZSCHE, Friedrich. O nascimento da tragédia ou helenismo e pessimismo. Tradução de J. Guinsburg. 2. ed. São Paulo: Companhia das Letras, 2000.

PÉCORA, Alcir (Org.). Por que ler Hilda Hilst. São Paulo: Globo, 2010. . Nota do organizador. In: HILST, Hilda. Júbilo, memória, noviciado da paixão. São Paulo: Globo, 2003. p.11-13.

PEREIRA, S. J. Isidro. Dicionário Grego-Português e Português-Grego. Porto: Livraria Apostolado da Imprensa, 1998.

ROUDINESCO, Elisabeth. Dicionário amoroso da psicanálise. Tradução de André Telles. Rio de Janeiro: Zahar, 2019. 
SOUSA, Eudoro. Introdução. In: ARISTÓTELES. Poética. Tradução de Eudoro de Sousa. Lisboa: Imprensa Nacional; Casa da Moeda, 1986. p. 13-101.

TINHORÃO, José Ramos. História social da música popular brasileira. 2. ed. São Paulo: Ed. 34, 2010.

Submetido em 25 de fevereiro de 2020

Aceito em 22 de abril de 2020

Publicado em 31 de maio de 2020 